\title{
Phytochemical Analysis in the Leaves of Chamaecrista nigricans (Leguminosae)
}

Tangavelou $\mathrm{AC}^{1 *}$, Viswanathan $\mathrm{MB}^{2}$, Balakrishna $\mathrm{K}^{3}$ and Patra $\mathrm{A}^{4}$

${ }^{1}$ Sri Paramakalyani Centre for Environmental Sciences, Manonmaniam Sundaranar University, Alwarkurichi, Tamil Nadu, India

${ }^{2}$ Department of Botany, Bharathidasan University, Tiruchirappalli 620024, Tamil Nadu, India

${ }^{3}$ Entomology Research Institute, Loyola College, Nungampakkam, Chennai 600034, Tamil Nadu, India

${ }^{4}$ Department of Chemistry, University College of Science, Kolkata, West Bengal, India

\begin{abstract}
Objective

In the present study, the plant Chamaecrista nigricans (Siruavuri in Tamil) was selected to isolate, elucidate and identify the chemical constituents present in it.

Methods

Leaves were collected, shade-dried, coarsely powdered using a pulvarizor, successively extracted with various solvents of increasing polarity such as hexane, chloroform and methanol using Soxhlet apparatus. Methanol leaf extract was used for isolation and identification of chemical constituents. Column chromatography (CC) and thin layer chromatography (TLC) were used for separation and purification of chemical constituents while the isolated pure compounds were identified using UV-VIS, IR, ${ }^{1} \mathrm{H}$ and ${ }^{13} \mathrm{C}$ NMR spectra. GC-MS analysis was carried out to identify the chemical constituents.
\end{abstract}

\section{Results}

Three anthraquinones such as emodin, chrysophanol and physcion were isolated and identified. GC-MS analysis helped to identify diisooctyl ester 1,2-benzenedicarboxylic acid, methyl ester, (Z, Z, Z)-9,12,15-octadecatrienoic acid, nitric acid nonyl ester, 4-C-methyl-myo-inositol, n-hexadecanoic acid, 2-methyl-butanoic acid, and, octadecanoic acid.

\section{Conclusion}

Medicinally valuable bioactive natural compounds in this plant proved its importance in drug industry for drug development against various diseases.

Keywords: Chamaecrista nigricans; Chemical constituents; Identification; Drug development

\section{Introduction}

The genus Chamaecrista (L.) Moench (Leguminosae) comprises of about 330 species [1] in the world most commonly found from Africa to Asia and also in South America. In India, 11 species are reported, of which 2 species are endemic. Chamaecrista nigricans (Vahl) Greene is an annual undershrub, locally known as Siruavuri in Tamil and commonly found in Thoothukudi, Tirunelveli and Virudhunagar districts of Tamil Nadu State in India. Locally, the leaves are used for the treatment of skin diseases. Traditionally, leaves are used as an appetite, fever, sore throat and various gastrointestinal disorders including diarrhea, peptic ulcer and in family planning [2-7], as an antipyretic and substituted for quinine in Senegal and Guinea and to heal wounds in Bamako region, Mali, West Africa [8]. Chemical constituents such as emodol, emodolanthrone and leucoanthocyanin have been reported from leaves $[2,9,10]$. Biological activities such as analgesic, anti-inflammatory, antidiarrheal, antimicrobial, anti-plasmodial, anti-ulcer, contraceptive and estrogenic properties have also been reported $[4-7,11]$.

\section{Experimental}

\section{Plant material}

Leaves were collected from the plains in Tirunelveli District, Tamil Nadu, India. Authentic herbarium specimen (MBV \& ACT 17210) was deposited in the Herbarium of the Sri Paramakalyani Centre for Environmental Sciences, Manonmaniam Sundaranar University, Alwarkurichi, Tamil Nadu, India.

\section{Plant materials and extraction}

Leaves of Chamaecrista nigricans (1 kg) were shade-dried, coarsely powdered using a pulvarizor, successive extracted with various solvents of increasing polarity such as hexane, chloroform and methanol using Soxhlet apparatus. Methanol leaf extract was selected for isolation and identification of phytoconstituents.

\section{Methods of separation}

Chromatographic techniques such as column chromatography (CC) and thin layer chromatography (TLC) were mainly used for separation and purification of phytoconstituents. Silica gel (60-120 mesh) columns of $90 \times 5 \mathrm{~cm}$ were prepared. The waxy material was removed by elution using hexane. Adding benzene, chloroform, ethyl acetate, methanol and their mixtures gradually increased the polarity of the eluting solvents. The elute fractions of $25-100 \mathrm{~mL}$ were collected and the solvents were distilled off on the Water Bath. The

*Corresponding author: Tangavelou AC, Sri Paramakalyani Centre for Environmental Sciences, Manonmaniam Sundaranar University, Alwarkurichi, Tamil Nadu, India, Tel: +91 9585147029; E-mail: ac.tangavelou@tdu.edu.in; actangavelou@hotmail.com

Received August 30, 2017; Accepted March 23, 2018; Published March 29, 2018

Citation: Tangavelou AC, Viswanathan MB, Balakrishna K, Patra A (2018) Phytochemical Analysis in the Leaves of Chamaecrista nigricans (Leguminosae). Pharm Anal Acta 9: 582. doi: 10.4172/2153-2435.1000582

Copyright: () 2018 Tangavelou AC, et al. This is an open-access article distributed under the terms of the Creative Commons Attribution License, which permits unrestricted use, distribution, and reproduction in any medium, provided the original author and source are credited. 
Citation: Tangavelou AC, Viswanathan MB, Balakrishna K, Patra A (2018) Phytochemical Analysis in the Leaves of Chamaecrista nigricans (Leguminosae). Pharm Anal Acta 9: 582. doi: 10.4172/2153-2435.1000582

Page 2 of 5

concentrates were spotted on TLC plates of silica gel G of $0.5 \mathrm{~mm}$ thickness coating. The plates $(20 \times 5 \mathrm{~cm})$ were developed with suitable solvents in a cylindrical TLC glass jar. The developed plates were airdried, sprayed $50 \%$ sulphuric acid and heated in an Oven at $110^{\circ} \mathrm{C}$ for 5 min. Similar fractions of TLC patterns were combined, concentrated and rechromatographed repeatedly over silica gel to isolate pure compounds.

\section{Methods of identification}

The isolated pure compounds were identified for the class to which they belong based on the properties and color reactions. The properties include melting point for solid, boiling point for liquid, $[\alpha]_{D}$ for optically active compounds and Rf value on TLC. However, equally informative data for plant constituents are spectral data. The instruments used were Shimadzu UV-VIS spectrophotometer in methanol for UV-VIS (ultra violet-visible) spectra, the $\mathrm{KBr}$ disc on Perkin-Elmer grating spectrophotometer for IR (infrared), ${ }^{1} \mathrm{H}$ and ${ }^{13} \mathrm{C}$ NMR spectra on Bruker FT-NMR instrument at $400 \mathrm{MHz}$ and $100 \mathrm{MHz}$ respectively, MS/GC-MS (Mass Spectroscopy/Gas ChromatographyMass Spectroscopy) using Shimadzu Instruments. Confirmation was done by direct comparison with authentic compounds [12].

Gas chromatography-Mass spectrometry (GC-MS): For GCMS analyses, the methanol extract was run on Perkin Elmer GC-MS system (GC Clarus 500) with Column Elite-1 (100\% Dimethyl poly siloxane), $30 \times 0.25 \mathrm{~mm} \times 1 \mu \mathrm{m} \mathrm{df}$. Oven temperature was programmed as follows: isothermal temperature at $50^{\circ} \mathrm{C}$ for $2 \mathrm{~min}$, then increased to $200^{\circ} \mathrm{C}$ at the rate of $10^{\circ} \mathrm{C} / \mathrm{min}$, then increased up to $280^{\circ} \mathrm{C}$ at the rate of $5^{\circ} \mathrm{C} / \mathrm{min}$ held for $9 \mathrm{~min}$. Ionization of the sample components was performed in the EI mode $(70 \mathrm{eV})$. The carrier gas was helium $(1 \mathrm{~mL} /$ min) and the sample injected was $2 \mu \mathrm{l}$. The detector was Mass detector turbo mass gold-Perkin Elmer. The total running time for GC was 36 min and software used was Turbomass 5.2. The individual constituents were identified by comparing their mass spectra with the spectra of known compounds stored in the NIST spectral database.

\section{Results}

The methanol leaf extract (200 g) was column chromatographed over silica gel (Acme's silica gel 60-120 mesh) in hexane and eluted with solvents of increasing polarity. Three anthraquinones (CN1, CN2 and CN3) were isolated and identified (Figures 1-3).

\section{Characterization of CN1 compound (Emodin)}

Elution with hexane:benzene (7:3) yielded orange-colored needles $(80 \mathrm{mg})$, crystallized from methanol (m.p. $\left.256-257^{\circ} \mathrm{C}\right)$. It was soluble in aqueous $\mathrm{Na}_{2} \mathrm{CO}_{3}$, conc. $\mathrm{H}_{2} \mathrm{SO}_{4}, \mathrm{NaOH}$ and $\mathrm{NH}_{3}$ and gave dark red solution. It gave positive ferric reaction for phenol. The compound gave orange color under daylight and UV light at $254 \mathrm{~nm}$. A single yellow spot was observed on TLC with silica gel $\left(\mathrm{R}_{\mathrm{f}}=0.59\right)$ and benzene:chloroform:ethylacetate (20:20:3) as the developing system, and it turned pink on exposure to $\mathrm{NH}_{3}$ vapor. It gave pink color with alcoholic magnesium acetate, a characteristic feature of anthraquinones.

UV $\lambda$ max nm: 220, 252, 264, 289, 436;

IR $v_{\max }^{K B r} \mathrm{~cm}^{-1}: 3388,1667,1622,1577,1563,1478,1369,1333$, $1301,1271,1217,1166,1101,1033,907,874,759$;

${ }^{1} \mathrm{H}$ NMR $\left(\boldsymbol{\delta}, \mathrm{CDCl}_{3} \mathbf{4 0 0} \mathbf{M H z}\right): 2.44\left(3 \mathrm{H}, \mathrm{s}, \mathrm{CH}_{3}\right), 6.66(1 \mathrm{H}, \mathrm{d}, \mathrm{J}=2.5$ $\mathrm{Hz}, \mathrm{H}-7), 7.07(1 \mathrm{H}, \mathrm{s}, \mathrm{H}-2), 7.31(1 \mathrm{H}, \mathrm{d}, \mathrm{J}=2.5 \mathrm{~Hz}, \mathrm{H}-5), 7.61(1 \mathrm{H}, \mathrm{br} \mathrm{s}$, $\mathrm{H}-4), 12.17$ (1H, s-OH), $12.27(1 \mathrm{H}, \mathrm{s}-\mathrm{OH})$;

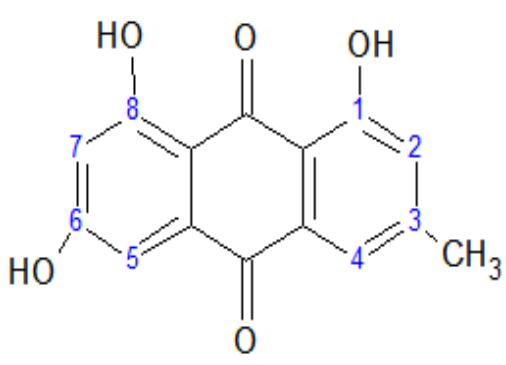

Figure 1: Emodin (1, 6, 8-trihydroxy, 3-methyl anthraquinone).

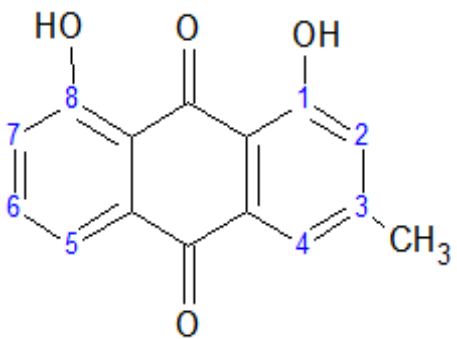

Figure 2: Chrysophanol (1, 8-dihydroxy, 3-methyl anthraquinone)

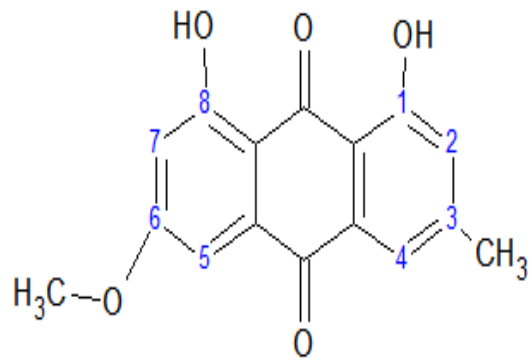

Figure 3: Physcion (1, 8-dihydroxy, 3-methyl-6-methoxy anthraquinone).

${ }^{13} \mathrm{C}$ NMR ( $\left.\delta, \mathbf{C D C l}_{3}, 100 \mathrm{MHz}\right): 22.3\left(-\mathrm{CH}_{3}\right), 108.7$ (C-5), 109.7 (C-12), 114.1 (s, C-13), 121.3 (C-4), 124.9 (C-2), 133.6 (C-14), 135.8 (C-11), 149.1 (C-3), 162.2 (C-1), 166.5 (C-6), 182.1 (C-10), 190.4 (C-9); and

EI-MS-m/z (\% rel. int.): $\mathrm{C}_{15} \mathrm{H}_{10} \mathrm{O}_{5} 270\left(\mathrm{M}^{+} 100 \%\right), 242$ (12), 213 (14), 185 (8), 155 (8), 141 (10).

\section{Characterization of CN2 compound (Chrysophanol)}

Elution with benzene:chloroform (1:1) gave yellow-colored needles (62 mg), crystallized from methanol (m.p. $195-197^{\circ} \mathrm{C}$ ). It was soluble in a solution of conc. $\mathrm{H}_{2} \mathrm{SO}_{4}$, aqueous $\mathrm{NaOH}$ and $\mathrm{NH}_{3}$ and gave dark red color. It gave positive ferric reaction for phenol. It was insoluble in 5\% aqueous $\mathrm{Na}_{2} \mathrm{CO}_{3}$. The compound was yellow color under daylight and UV light at $254 \mathrm{~nm}$. A single spot was observed on TLC with silica gel $(\mathrm{Rf}=0.61)$ and chloroform: ethylacetate $(2: 1)$ as solvent system, and the spot turned pink on exposure to $\mathrm{NH}_{3}$ vapor. The compound showed red color with methanolic $\mathrm{NaOH}$ and alcoholic magnesium acetate, a characteristic feature of anthraquinones.

IR $v_{\max }^{K B r} \mathrm{~cm}^{-1}: 3047,2848,1677,1627,1475,1452,1270,1208$, 1159, 1086, 1024, 902, 869, 839, 752;

${ }^{1} \mathrm{H}$ NMR ( $\left.\boldsymbol{\delta}, \mathrm{CDCl}_{3}, 400 \mathrm{MHz}\right): 2.45\left(3 \mathrm{H}, \mathrm{s}, \mathrm{CH}_{3}-3\right), 7.09$ (1H, brs, 
Citation: Tangavelou AC, Viswanathan MB, Balakrishna K, Patra A (2018) Phytochemical Analysis in the Leaves of Chamaecrista nigricans (Leguminosae). Pharm Anal Acta 9: 582. doi: 10.4172/2153-2435.1000582

H-2), $7.29(1 \mathrm{H}$, brd, J=8.0 Hz, H-7), $7.64(1 \mathrm{H}$, brs, H-4), 7.69 (1H, brs, H-6), $7.81(1 \mathrm{H}, \mathrm{brd}, \mathrm{J}=8.0 \mathrm{~Hz}, \mathrm{H}-5), 12.0(1 \mathrm{H}, \mathrm{s},-\mathrm{OH}), 12.11(1 \mathrm{H}, \mathrm{s},-\mathrm{OH})$;

${ }^{13} \mathrm{C}$ NMR ( $\left.\delta, \mathbf{C D C l}_{3}, 100 \mathrm{MHz}\right): 22.3\left(-\mathrm{CH}_{3}\right), 108.7$ (C-5), 109.7 (C12), 114.1 (s, C-13), 121.3 (C-4), 124.9 (C-2), 133.6 (C-14), 135.8 (C-11), 149.1 (C-3), 162.2 (C-1), 166.5 (C-6), 182.1 (C-10), 190.4 (C-9); and

EI-MS-m/z (\% rel. int.): $\mathrm{C}_{15} \mathrm{H}_{10} \mathrm{O}_{5} 270\left(\mathrm{M}^{+} 100 \%\right), 239(8), 226(10)$, 197 (9), $152(6), 127$ (4).

\section{Characterization of $\mathrm{CN} 3$ compound (Physcion)}

Elution with chloroform: methanol (1:1) gave yellow-colored needles $(28 \mathrm{mg})$, crystallized from ethylacetate (m.p. 206-207 $\left.{ }^{\circ} \mathrm{C}\right)$. It was soluble in the solution of conc. $\mathrm{H}_{2} \mathrm{SO}_{4}, \mathrm{NaOH}$ and $\mathrm{NH}_{4} \mathrm{OH}$ and gave dark red color. It gave positive ferric reaction for phenol. It was insoluble in $5 \%$ aqueous $\mathrm{Na}_{2} \mathrm{CO}_{3}$. The compound gave yellow color under daylight and UV light at $254 \mathrm{~nm}$. A single spot was observed on TLC over silica gel $(\mathrm{Rf}=0.77)$ and developed with chloroform: methanol (5:2) as the solvent system, which turned pink on exposure to $\mathrm{NH}_{3}$ vapor. The compound showed red color with methanolic $\mathrm{NaOH}$ and alcoholic magnesium acetate a characteristic feature of anthraquinones.

UV $\lambda \max$ nm: 249, 265, 287, 406 (rh), 432;

IR $v_{\max }^{K B r} \mathrm{~cm}^{-1}: 3405,2921,2833,1628,1478,1365,1325,1273$, 1225, 1160, 1033, 978, 900, 874, 849, 759, 714; ${ }^{1} \mathbf{H}$ NMR ( $\boldsymbol{\delta}, \mathbf{C D C l}_{3}, \mathbf{4 0 0}$ MHz): $2.45\left(3 \mathrm{H}, \mathrm{s}, \mathrm{CH}_{3}\right), 3.94\left(3 \mathrm{H}, \mathrm{s},-\mathrm{OCH}_{3}\right), 6.69(1 \mathrm{H}, \mathrm{d}, \mathrm{J}=3.0 \mathrm{~Hz}$, $\mathrm{H}-7), 7.08(1 \mathrm{H}$, brs, H-2), $7.36(1 \mathrm{H}, \mathrm{d}, \mathrm{J}=3.0 \mathrm{~Hz}, \mathrm{H}-5), 7.62(1 \mathrm{H}, \mathrm{d}, \mathrm{J}=3.0$ $\mathrm{Hz}), 12.12(1 \mathrm{H}, \mathrm{s}, \mathrm{OH}), 12.31(1 \mathrm{H}, \mathrm{s}, \mathrm{OH})$; and

EI-MS-m/z (\%): $284\left(\mathrm{M}^{+}, 100\right), 260$ (18), 240 (12), 226 (11), 189 (6), 167 (7), 139 (10), $111(4)$

\section{GC-MS analysis}

GC-MS analysis of methanol extract showed seven peaks indicating the presence of seven phytochemical constituents (Table 1, Figures 4-10). They are nitric acid nonyl ester; 4-C-methyl-myo-inositol; 2-methyl-butanoic acid; n-hexadecanoic acid; methyl ester, (Z, Z, Z)9, 12, 15-octadecatrienoic acid; octadecanoic acid and diisooctyl ester 1,2-benzenedicarboxylic acid respectively. Of which, 3 compounds each belonged to aliphatic esters and saturated fatty acids and one compound belonged to inositol. Comparatively, 4-C-methyl-myoinositol was present in major quantity $(57.01 \%)$ followed by diisooctyl ester 1,2-benzenedicarboxylic acid (41.22\%) respectively.

\section{Discussion}

All the three compounds of emodin, chrysophanol and physician developed red color with methanolic $\mathrm{NaOH}$ and magnesium acetate, characteristic of anthraquinones [13]. The development of pink color under $5 \% \mathrm{KOH}$ in methanol on TLC silica gel indicates the presence of hydroxyanthraquinones $[14,15]$. All the compounds gave positive ferric reaction for phenol.

\section{Identification of CN1 compound (Emodin)}

$\mathrm{UV} v_{\max }^{K B r} \mathrm{~cm}^{-1}$ at $436 \mathrm{~nm}$ indicates the presence of chelated hydroxyl groups in the compound. Characteristic IR peaks at 3388 ,<smiles>CCC(C)C</smiles>

Figure 4: 2-Methyl-butanoic acid.<smiles>CC(O)(O)c1c(O)c(O)c(O)c(O)c1O</smiles>

Figure 5: 4-C-Methyl-myo-inositol.<smiles>CC/C=C/C/C=C/C/C=C/CCCCCCCC(=O)OC</smiles>

Figure 6: Methyl ester, (Z, Z, Z)-9, 12, 15-octadecatrienoic acid<smiles>O=C(O)OC(=O)c1ccccc1C(=O)O</smiles>

Figure 7: Diisooctyl ester 1, 2-benzenedicarboxylic acid.

\begin{tabular}{|c|c|c|c|c|c|}
\hline Name of the compound & Nature of compounds & Retention time & Molecular formula & Molecular weight & Peak area \% \\
\hline $\begin{array}{c}\text { Diisooctyl ester 1, } \\
\text { 2-benzenedicarboxylic acid }\end{array}$ & Aliphatic Ester & 24.67 & $\mathrm{C}_{24} \mathrm{H}_{38} \mathrm{O}_{4}$ & 390 & 41.33 \\
\hline $\begin{array}{c}\text { Methyl ester, (Z, Z, Z)-9, 12, } \\
\text { 15-octadecatrienoic acid }\end{array}$ & Aliphatic Ester & 18.81 & $\mathrm{C}_{19} \mathrm{H}_{32} \mathrm{O}_{2}$ & 292 & 0.46 \\
\hline Nitric acid nonyl ester & Aliphatic Ester & 7.90 & $\mathrm{C}_{9} \mathrm{H}_{19} \mathrm{NO}_{3}$ & 189 & 0.05 \\
\hline 4-C-Methyl-myo-inositol & Inositol & 13.63 & $\mathrm{C}_{7} \mathrm{H}_{14} \mathrm{O}_{6}$ & 194 & 57.01 \\
\hline n-Hexadecanoic acid & Saturated Fatty acid & 16.14 & $\mathrm{C}_{16} \mathrm{H}_{32} \mathrm{O}_{2}$ & 256 & 1.01 \\
\hline 2-Methyl-butanoic acid & Saturated Fatty acid & 15.50 & $\mathrm{C}_{5} \mathrm{H}_{10} \mathrm{O}_{2}$ & 102 & 0.10 \\
\hline Octadecanoic acid & Saturated Fatty acid & 19.12 & $\mathrm{C}_{18} \mathrm{H}_{36} \mathrm{O}_{2}$ & 284 & 0.05 \\
\hline
\end{tabular}

Table 1: GC-MS Analysis of leaves of Chamaecrista nigricans. 


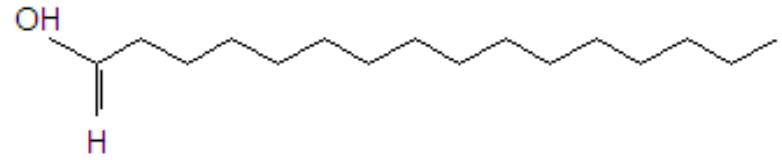

Figure 8: n-Hexadecanoic acid.

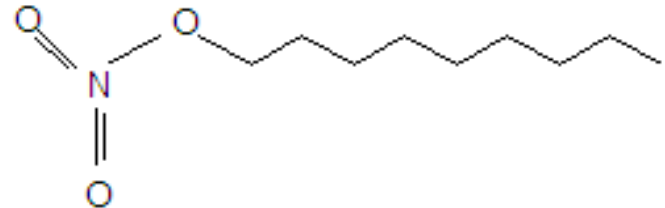

Figure 9: Nitric acid nonyl.

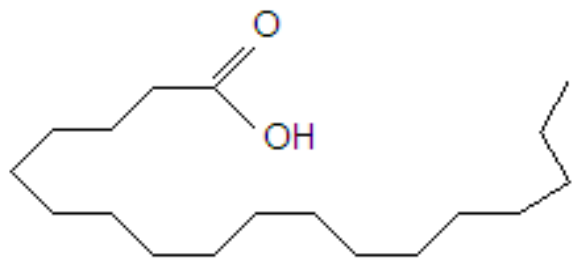

Figure 10: Octadecanoic acid.

$1667,1622,1577,1563,1478,1416,907,874,759$ and $720 \mathrm{~cm}^{-1}$ were observed for hydroxyl, non-chelated, chelated carbonyl groups and aromatic ring moieties respectively [16]. The ${ }^{1} \mathrm{H}$ NMR spectrum revealed the presence of an aromatic methyl group at $\delta 2.44$, typical of a $\beta$-methyl to $\mathrm{C}-1 \mathrm{OH}$ bonded to the $\mathrm{C}-3$ atom. It also showed 2 metacoupled protons appearing as broad singlet at $\delta 7.07$ and 7.61 assigned to $\mathrm{H}-2$ and $\mathrm{H}-4$. Two other metacoupled aromatic protons $(\mathrm{J}=2.5 \mathrm{~Hz})$ appearing at $\delta 7.31$ and 6.66 . They were assigned to $\mathrm{H}-5$ and $\mathrm{H}-7$ respectively. Two broad one proton singlets appearing at $\delta 12.17$ and 12.27 were assignable to the chelated hydroxyls at $\mathrm{C}-1$ and $\mathrm{C}-8$. These data suggested $\mathrm{CN} 1$ to be emodin. The ${ }^{13} \mathrm{C} \mathrm{NMR}$ spectrum also confirmed the structure and it revealed the presence of methyl group at $\delta 22.4$. The mass spectrum also showed $\mathrm{M}^{+}$at $\mathrm{m} / \mathrm{z}$ 270 corresponding to the molecular formula $\mathrm{C}_{15} \mathrm{H}_{10} \mathrm{O}_{5}$ for emodin (1, 6, 8-trihydroxy, 3-methylanthraquinone). All these spectral data reported were comparable with those of emodin $[17,18]$. This compound was first reported in 1925 as frangula-emodin from the fungi Dermocybe sanquinens [19], later from Penicillium sp. [20], Aspergillus sp. [21], lichens [22] and higher plants including Cassia spp. [23,24], Rheum and Rumex spp. [16], Polygonum spp. and Rhamnus [25,26] and Ventilago spp. [27]. Thus the anthraquinone (CN1) was identified as emodin.

\section{Identification of $\mathrm{CN} 2$ compound (Chrysophanol)}

$\mathrm{UV} v_{\max }^{K B r} \mathrm{~cm}^{-1}$ at $436 \mathrm{~nm}$ indicates the presence of chelated hydroxyl groups in the compound. Characteristic IR peaks at 3047, 1677, 1627, 1475, 1452, 902, 869 and $752 \mathrm{~cm}^{-1}$ were observed for hydroxyl, non-chelated, chelated carbonyl groups and aromatic ring moieties respectively [16]. The ${ }^{1} \mathrm{H}$ NMR spectrum reveals the presence of an aromatic methyl group at $\delta 2.45$, typical of a $\beta$-methyl bonded to the C-3 atom. Two broad singlets at $\delta 7.09$ and 7.64 are attributed to $\mathrm{H}-2$ and $\mathrm{H}-4$ respectively. Two one proton broad doublets at $\delta 7.81$ $(\mathrm{d}, \mathrm{J}=8.0 \mathrm{~Hz})$ and $7.29(\mathrm{~d}, \mathrm{~J}=8.0 \mathrm{~Hz})$ were assigned to $\mathrm{H}-5$ and $\mathrm{H}-7$ respectively and the two singlet proton signals at $\delta 12.0(\mathrm{~s}, 1 \mathrm{H})$ and $12.11(\mathrm{~s}, 1 \mathrm{H})$ were assignable to chelated hydroxyl groups. The mass spectrum of the compound showed $\mathrm{M}^{+}$at $\mathrm{m} / \mathrm{z} 254$ corresponding to the molecular formula $\mathrm{C}_{15} \mathrm{H}_{10} \mathrm{O}_{4}$ for chrysophanol (1, 8-dihydroxy, 3-methyl anthraquinone). All these spectral data reported were comparable with those of chrysophanol $[17,18]$. This compound was reported from the fungi Phoma foveata [28], lichens, Asahinae chrysantha [22] and higher plant families belonging to Cassia spp. [23,24], Rheum spp. [15], Rumex and Polygonum spp. [29], Rhamnus and Ventilago spp. [27]. Thus the anthraquinone (CN2) was identified as chrysophanol.

\section{Identification of $\mathrm{CN} 3$ compound (Physcion)}

$\mathrm{UV} v_{\max }^{K B r} \mathrm{~cm}^{-1}$ at $432 \mathrm{~nm}$ indicates the presence of chelated hydroxyl groups in the compound. Characteristic IR peaks at 3405 , $1628,1478,977,899,874,758$ and $714 \mathrm{~cm}^{-1}$ were observed for hydroxyl, chelated carbonyl groups and aromatic ring moieties respectively [16]. The ${ }^{1} \mathrm{H}$ NMR spectrum revealed the presence of an aromatic methyl group at $\delta 2.44$, typical of a $\beta$-methyl bonded to the $\mathrm{C}-3$ atom and a methoxy group at $\delta 3.94$ attached to C- 6 atom. Two broad singlets at $\delta 7.07$ and 7.61 which are attributed to $\mathrm{H} 2$ and $\mathrm{H} 4$ respectively and two one proton meta-coupled doublets at $\delta 6.66(\mathrm{~d}, \mathrm{~J}=3.0 \mathrm{~Hz})$ and $7.31(\mathrm{~d}$, $\mathrm{J}=3.0 \mathrm{~Hz}$ ) were assignable to $\mathrm{H}-5$ and $\mathrm{H}-7$ respectively. The two broad single proton signal at $\delta 12.12(\mathrm{~s}, 1 \mathrm{H})$ and $12.31(\mathrm{~s}, 1 \mathrm{H})$ represented chelated hydroxyl groups. The mass spectrum of the compound showed $\mathrm{M}^{+}$at $\mathrm{m} / \mathrm{z} 284$ corresponding to the molecular formula $\mathrm{C}_{16} \mathrm{H}_{12} \mathrm{O}_{5}$ corresponding to physcion (1, 8-dihydroxy, 3-methyl-6-methoxy anthraquinone). All these spectral data reported were comparable with those of physcion $[17,18]$. This compound was widely distributed in fungi including Aspergillus spp., Penicillium spp., Lichens eg. Parmelia spp., higher plants including Cassia spp. [23,24], Rheum spp. [15], Rumex and Polygonum spp. [29] and Rhamnus and Ventilago spp. [27]. Thus the anthraquinone (CN3) was identified as physcion.

All these three anthraquinones possess a wide range of pharmacological activities. Emodin possesses a wide spectrum of biological activities such as anticancer, anti-inflammatory, antioxidant, antimicrobial, hepatoprotective [30-34]. Chrysophanol has antibacterial, lipid-lowering effects $[35,36]$ while physcion has been reported for antimicrobial, anti-inflammatory, anti-cancer and hepatoprotective activities [37-41].

GC-MS analysis revealed the presence of three aliphatic compounds, three saturated fatty acids and single inositol compound. All these compounds are medicinally valuable and are reported to have pharmacological effects in experimental animals. The compound $\mathrm{n}$-hexadecanoic acid is a fatty acid which has been reported to possess potential mosquito larvicide and anti-inflammatory activity $[42,43]$ and 2-methyl-butanoic acid for antibacterial activity [44]. Octadecanoic acid (stearic acid) has been to have anti-inflammatory activity [45] and also accelerates the recovering of hepatic dysfunction of liver damage in rats [46]. The compound 4-C-methyl-myo-inositol was found to be present in major quantity and it has been reported as a promising treatment for the prevention of ovarian hyperstimulation syndrome in experimental rats.

\section{Conclusion}

In the present study, it is concluded that the presence of these medicinally valuable bioactive natural compounds including three anthraquinones in C. nigricans proved its importance in drug industry for drug development against various diseases. 
Citation: Tangavelou AC, Viswanathan MB, Balakrishna K, Patra A (2018) Phytochemical Analysis in the Leaves of Chamaecrista nigricans (Leguminosae). Pharm Anal Acta 9: 582. doi: 10.4172/2153-2435.1000582

Page 5 of 5

\section{Acknowledgement}

The first author thanks the Council of Scientific and Industrial Research (CSIR), New Delhi, for the award of Senior Research Fellowship [CSIR Award No.9/652(13)] to carry out this research work.

\section{References}

1. Lewis GP (2005) Tribe Cassieae. Legumes of the world. Royal Botanic Gardens, Kew. pp: 111-125.

2. Dalziel JM (1937) The useful plants of West Tropical Africa. The Crown Agents for the Overseas Colonies. pp: 612

3. Council of Scientific \& Industrial Research (1985). The Wealth of India: A dictionary of Indian raw materials \& industrial products. Publications \& Information Directorate, Council of Scientific \& Industrial Research, New Delhi.

4. Akah PA, Orisakwe OE, Gamaniel KS, Shittu A (1998) Evaluation of Nigerian traditional medicines: II effects of some Nigerian folk remedies on pepetic ulcer. J Ethnopharmacol 62: 123-127.

5. Chidume FC, Gamaniel K, Amos S, Akah P, Obodozie O, et al. (2001) Pharmacological activity of the methanolic extract of Cassia nigricans leaves. Indian J Pharmacol 33: 350-356.

6. Nwafor PA, Okwuasaba FK (2001a) Contraceptive and esterogenic effect of a methanolic extract of Cassia nigricans leaves in Experimental animals. Pharm Biol 39: 424-428.

7. Nwafor PA, Okwuasaba FK (2001b) Effect of methanolic extract of Cassia nigricans leaves on rat gastrointestinal tract. Fitoterapia 72: 206-214.

8. Diallo D, Sogn C, Samaké FB, Paulsen BS, Michaelsen TE, et al. (2002) Wound healing plants in Mali, the Bamako Region: An ethnobotanical survey and complement fixation of water extracts from selected plants. Pharm Biol 40: $117-128$

9. Sundararaj D, Balasubramanyam G (1959) Guide to the economic plants of South India. Amudha Nilyam Private Limited, Madras.

10. Irwin FR (1961) Woody plants of Ghana with special reference to their uses. Oxford University Press, London.

11. Silva O, Duarte A, Cabrita J, Pimentel M, Diniz A, et al. (1996) Antimicrobial activity of Guinea-Bissau traditional remedies. J Ethnopharmacol 50: 55-59.

12. Harborne JB (1998) Phytochemical methods: A guide to modern techniques of plant analysis. Chapman \& Hall, London.

13. Robinson T (1963) The Organic constituents of higher plants: Their chemistry and interrelationships.

14. Rai PP, Shok M (1981) Burgess, Minneapolis, Minn. Thin-layer chromatography of hydroxyanthraquinones in plant extracts. Chromatographia 14: 599-600.

15. Ma X, Chen Y, Hui R (1989) Analysis of anthraquinones in Rheum franzenbachi Munt (Rhubarb) by thin-layer chromatography. Chromatographia 27: 465-466.

16. Omur-Demirezer L, Kuruuzum-Uz A, Bergere I, Schiewe HJ, Zeeck A (2001) The structure of antioxidant and cytotoxic agents from natural source: Anthraquinones and tannins from roots of Rumex patientia. Phytochemistry 58: 1213-1217.

17. Lee CK, Lee PH, Kuo IH (2001) Chemical constituents from the aril of Cassia fistula L. J Chinese Chem Soc 48: 1053-1058.

18. Meselhy MR (2003) Constituents from Molghat, the roots of Glossostemon bruguieri (Desf.). Molecules 8: 614-621.

19. Kogl F, Postowsky JJ (1925) Untersuchungen über Pilzfarbstoffe. II. Über die Farbstoffe des blutroten Hautkopfes (Dermocybe sanguinea Wulf.). Justus Liebigs Ann Chem 444: 1-7.

20. Shibata S, Udagawa S (1963) Metabolic products of fungi. XIX. Isolation of rugulosin from Penicllium brunneum Udagawa. Chem Pharm Bull 11: 402-403.

21. Anke H, Kolthum I, Zahner H, Laatsch H (1980) Metabolic products of microorganisms. 185. The anthraquinones of the Aspergillus glaucus Group. 1. Occurrence, isolation, identification and antimicrobial activity. Arch Microbiol 126: 223-230.

22. Mishchenko NP, Stepanenko S, Krivoshcekova OE, Maksimov OB (1980) Anthraquinones of the lichens Asahinea chrysantha. Chemistry of Natural Compounds, 16: 117-121.
23. Ganapaty S, Thomas PS, Ramana KV, Vidhyadhar K, Chakradhar V (2002) A review of phytochemical studies of Cassia species. J Nat Remedies 2: 102-120.

24. Manojlovic I, Bogdanovic-Dusanovic G, Gritsanapan W, Manojlovic N (2006) Isolation and identification of anthraquinones of Caloplaca cerina and Cassia tora. Chem Pap 60: 466-468.

25. Dwivedi SP, Pandey VB, Shah AH, Rao YB (1988) Chemical constituents of Rhamnus procumbens and pharmacological actions of emodin. Phytotheraphy Res 2: 51-53.

26. Goel RK, Das Gupta G, Ram SN, Pandey VB (1991) Antiulcerogenic and antiinflammatory effects of emodin, isolated from Rhamnus triquerta Wall. Indian J Exp Biol 29: 230-232.

27. Izhaki I (2002) Emodin: A secondary metabolite with multiple ecological functions in higher plants. New Phytol 155: 205-217.

28. Bick IRC, Rhee C (1966) Anthraquinone pigments from Phoma foveata Foister. Biochem J 98: 112-116.

29. Yao S, Li Y, Kong L (2006) Preparative isolation and purification of chemical constituents from the root of Polygonum multiflorum by high-speed countercurrent chromatography. J Chromatogr A 1111: 64-71.

30. Lin CC, Chang CH, Yang JJ, Namba T, Hattori M (1996) Hepatoprotective effects of emodin from Ventilago leiocarpa. J Ethnopharmacol 52: 107-111.

31. Dave $H$, Ledwani $L$ (2012) A review on anthraquinones isolated from Cassia species and their applications. Indian J Nat Prod Resour 3: 291-319.

32. Hsu SC, Chung JG (2012) Anticancer potential of emodin. BioMedicine 2: 108-116

33. Dong X, Fu J, Yin X, Cao S, Li X, et al. (2016) Emodin: A review of its pharmacology, toxicity and pharmacokinetics. Phytother Res 30: 1207-1218.

34. Sharma R, Tiku AB, Giri A (2017) Pharmacological properties of emodin Anthraquinone derivatives. J Nat Prod Resour 3: 97-101.

35. Coopoosamy RM, Magwa ML (2006) Antibacterial activity of chrysophano isolated from Aloe excelsa (Berger). African J Biotech 5: 1508-1510.

36. Chen CQ, Wang YQF, Yu-Shui Xie YS, Yin ZF, Xu ZJ, et al. (2015) Application of chrysophanol in zebrafish to reduce dietary introduced lipid and its possible mechanism. Int J Clin Exp Med 8: 10558-10567.

37. Tamokou JDD, Tala MF, Wabo HK, Kuiate JR, Tane P (2009) Antimicrobia activities of methanol extract and compounds from stem bark of Vismia rubescens. J Ethnopharmacol 124: 571-575.

38. Zhao YL, Wang JB, Zhou GD, Shan LM, Xiao XH (2009) Investigations of free antraquinones from rhubarb against $\alpha$-naphthylisothiocyanate-induced cholestatic liver injury in rats. Basic Clin Pharmacol Toxicol 104: 463-469.

39. Almeida AP, Dethoup T, Singburaudom N, Lima R, Vasconcelos MH, et al (2010) The in vitro anticancer activity of the crude extract of the spongeassociated fungus Eurotium cristatum and its secondary metabolites. J Nat Pharma 1: 25-29.

40. Ghosh S, Sarma MD, Patra A, Hazra B (2010) Anti-inflammatory and anticancer compounds isolated from Ventilago madraspatana Gaertn., Rubia cordifolia Linn. and Lantana camara Linn. J Pharm Pharmacol 62: 1158-1166.

41. Wijesekara I, Zhang C, Van TQ, Vo TS, Li YX, et al. (2014) Physcion from marine-derived fungus Microsporum sp. induces apoptosis in human cervical carcinoma HeLa cells. Microbiol Res 169: 255-261.

42. Rahuman AA, Gopalakrishnan G, Ghouse BS, Arumugam S, Himalayan (2000) Effect of Feronia limonia on mosquito larvae. Fitoterapia 71: 553-555.

43. Aparna V, Dileep KV, Mandal PK, Karthe P, Sadasivan C, et al. (2012) Antiinflammatory property of $n$-hexadecanoic acid: Structural evidence and kinetic assessment. Chem Biol Drug Des 80: 434-439.

44. Hayashida-Soiza G, Uchida A, Mori N, Kuwahara Y, Ishida Y (2008) Purification and characterization of antibacterial substances produced by a marine bacterium Pseudoalteromonas haloplanktis strain. J Applied Microbio 105: 1672-1677.

45. Shaw B, Lambert S, Wong MH, Ralston JC, Stryjecki C, et al. (2013) Individual saturated and monounsaturated fatty acids trigger distinct transcriptional networks in differentiated 3T3-L1 preadipocytes. J Nutrigenetics Nutrigenomics 6: $1-15$

46. Goradel NH, Ali EM, Darabi M, Roshangar L, Asadi M, et al. (2016) Improvement of liver cell therapy in rats by dietary stearic acid. Iranian Biomedical J 20: 217-222. 